\title{
NA17 Peptide (Amino acid sequence VLPDVFIRCV)
}

National Cancer Institute

\section{Source}

National Cancer Institute. NA17 Peptide (Amino acid sequence VLPDVFIRCV). NCI

Thesaurus. Code C29276.

A synthetic peptide vaccine derived from the melanoma antigen NA17. Dendritic cells

(DC) harvested from a cancer patient may be exposed to or pulsed with the NA17 peptide (VLPDVFIRCV). Autologous vaccination with these altered dendritic cells may stimulate the host immune system to mount a cytotoxic $T$ lymphocyte $(C T L)$ response ag ainst tumor cells positive for NA17, resulting in decreased tumor growth. (NCI04) 